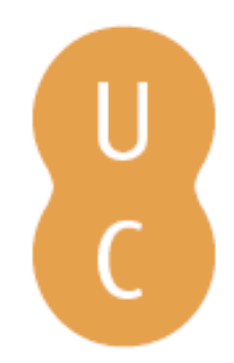

\title{
pompalina
}

\section{Banquet and philhellenism in the Lives of Flamininus and Aemilius Paullus}

\author{
Autor(es): $\quad$ Tröster, Manuel
}

Publicado por: Imprensa da Universidade de Coimbra; Centro de Estudos Clássicos e

URL

persistente: URI:http://hdl.handle.net/10316.2/31990

DOI: $\quad$ DOI:http://dx.doi.org/10.14195/978-989-8281-17-3_15

Accessed : $\quad$ 26-Apr-2023 12:07:11

A navegação consulta e descarregamento dos títulos inseridos nas Bibliotecas Digitais UC Digitalis, UC Pombalina e UC Impactum, pressupõem a aceitação plena e sem reservas dos Termos e Condições de Uso destas Bibliotecas Digitais, disponíveis em https://digitalis.uc.pt/pt-pt/termos.

Conforme exposto nos referidos Termos e Condições de Uso, o descarregamento de títulos de acesso restrito requer uma licença válida de autorização devendo o utilizador aceder ao(s) documento(s) a partir de um endereço de IP da instituição detentora da supramencionada licença.

Ao utilizador é apenas permitido o descarregamento para uso pessoal, pelo que o emprego do(s) título(s) descarregado(s) para outro fim, designadamente comercial, carece de autorização do respetivo autor ou editor da obra.

Na medida em que todas as obras da UC Digitalis se encontram protegidas pelo Código do Direito de Autor e Direitos Conexos e demais legislação aplicável, toda a cópia, parcial ou total, deste documento, nos casos em que é legalmente admitida, deverá conter ou fazer-se acompanhar por este aviso.

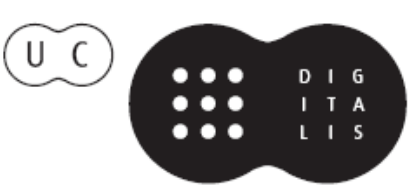




\section{Symposion and Philanthropia in Plutarch}

\section{José Ribeiro Ferreira, Delfim Leão Manuel Troster e Paula Barata Dias (eds.)}

IMPRENSA DA UNIVERSIDADE DE COIMBRA 


\title{
BANQUET AND PHILHELLENISM IN THE LIVES OF FLAMININUS AND AEMILIUS PAULLUS
}

\author{
Manuel Tröster \\ University of Coimbra
}

\begin{abstract}
The Lives of Flamininus and Aemilius Paullus are good examples of Plutarch's tendency to judge his Roman heroes according to their Hellenic qualities and benefactions to Greeks. While modern scholars rightly stress that both politicians were mainly driven by Roman interests and personal ambition, the biographer chooses primarily to highlight their philanthropic nature as well as their favourable attitude to Greek liberty and culture. Conspicuously, his praise is particularly generous in two episodes related to feasts and spectacles. Following the proclamation of liberty at the Isthmian Games, Flamininus' policies are celebrated in the course of a banquet, with his achievements being judged equal or superior to those of the most eminent Greek statesmen of the past (Flam. 11). In the Aemilius, it is the protagonist himself who organises splendid feasts in a way that inspires profound admiration on the part of the Greeks (Aem.28). While Livy's account suggests that the victory celebrations at Amphipolis should primarily be seen as a show of Roman power, Plutarch essentially describes the event as a pleasant entertainment with a view to revealing Aemilius' personal qualities. Greek-style festivals and banquets thus provide a most suitable background for presenting the 'liberators' of Greece as exemplars of philhellenism and philanthrôpia.
\end{abstract}

While much attention continues to be devoted to the significance of the Parallel Lives as an expression of a shared Graeco-Roman identity among the imperial élite, recent scholarship has tended to stress the essential Greekness of Plutarch's outlook and criteria of judgement ${ }^{1}$. Evidently, this does not imply that the Greek heroes are systematically presented as superior to their Roman pairs ${ }^{2}$, yet it is important to acknowledge that the great men of the res publica are often accorded praise and blame on the basis of their attitude to Hellenic culture and their benefactions to Greeks ${ }^{3}$. Thus, the representatives of Rome are expected to prove their worth on a playing field defined by the norms and values of Greek civilisation, and it is by displaying $\pi \rho \alpha o ́ \tau \eta \zeta, ~ \varphi \imath \lambda \alpha v \theta \rho \omega \pi i ́ \alpha$, and other qualities cherished by Second Sophistic authors that they earn recognition and acclaim ${ }^{4}$.

${ }^{1}$ Cf. T. E. Duff, 1999, pp. 287-309; R. Preston, 2001, pp. 97-109; S. Goldhill, 2002, pp. 254-71; G. Roskam, 2004, pp. 255-64; also G. D’Ippolito, 2005, pp. 182-6; M. A. O. Silva, 2007.

${ }^{2}$ Rather the protagonists are treated as equals, as can be seen most clearly in the synkriseis. Cf. T. E. Duff, 1999, pp. 257-62, who argues that this is meant to focus the reader's attention on the moral issues involved. Also note J. Boulogne, 1994, pp. 62-9; idem, 2000, who thinks of a cultural programme.

${ }^{3}$ In particular, this applies to their Hellenic education. Cf. C. B. R. Pelling, 1989; S. Swain, 1990; also idem, 1996, pp. 139-144; further L. A. García Moreno, 1995, pp. 136-47; idem, 2002.

${ }^{4}$ On Plutarch's use of these concepts cf. H. M. Martin JR., 1960; idem, 1961; C. Panagopoulos, 1977, pp. 216-22; J. De Romilly, 1979, pp. 275-307; F. Frazier, 1996, pp. 231-9. 
The Lives of Flamininus and Aemilius Paullus may be particularly relevant in this respect since the two protagonists were not only benefactors but also conquerors of Greece ${ }^{5}$. Both of them are commonly viewed as exponents of philhellenism, yet it is perfectly clear that this concept cannot be separated from the parameters of Roman power, public relations, and political manoeuvring ${ }^{6}$. In the case of Aemilius Paullus, it is surely significant that the sources place at least as much emphasis on his devotion to mos maiorum as on his admiration for Greece, but the actions of Flamininus, too, must be understood primarily with reference to the pursuit of glory, honour, and dignity in the competitive culture of Republican Rome ${ }^{7}$.

This less romantic perspective is by no means absent from Plutarch's biographical portraits. However, the two statesmen's commitment to Roman values and the affirmation of Roman power is not viewed as a serious limitation on their philhellenic inclinations and policies. In the Flamininus, the two spheres are to a large extent structurally separated: while political machinations do play a certain rôle in the account of the general's command in Greece (Flam. 7.1-3; 13.1-4), they are clearly secondary to the focus on

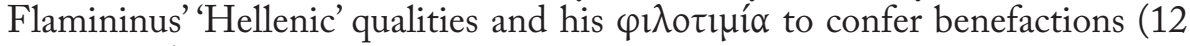
and passim). Later on, his return to Rome marks the beginning of excessive, unreasonable, and untimely ambition both in destructive conflicts with his peers and in the relentless hunt for Hannibal (18.3-21.14). Consequently, Plutarch's overall judgement of the 'liberator' of Greece is by no means wholly flattering or uncritical ${ }^{9}$, but this does not diminish his generous praise for the protagonist's philhellenism.

Contrary to the biographer's usual practice of ascribing both positive and negative qualities to his heroes, the Life of Aemilius provides an exceptionally favourable portrait of the victor of Pydna, which Alberto Barzanò has even called a piece of "pagan hagiography"10. Above all, the protagonist is depicted as a wise educator of those around him in matters

${ }^{5}$ On Plutarch's attitude to the 'liberators' of Greece cf. J. M. Bremer, 2005.

${ }^{6}$ On the political dimension of Roman philhellenism cf. esp. J.-L. FERrary, 1988, pp. 96117 and passim. Consequently, the impact of 'sentimental' considerations and deference to Greek culture should not be overestimated. Cf. E. Badian, 1970, pp. 53-7; E. S. Gruen, 1984, pp. 267-72; R. M. Errington, 1999; also N. Petrochilos, 1974, pp. 105-11.

${ }^{7}$ Cf., e.g., H. Веск, 2005, pp. 368-93; R. Pfeilschifter, 2005, pp. 325-42 and passim.

${ }^{8}$ On the dual structure of the Life cf. C. B. R. Pelling, 1997, pp. 309-18; also idem, 1989, pp. 208-14; J. J. Walsh, 1992, pp. 219-21.

${ }^{9}$ Cf., e.g., R. Flacelière \& E. Chambry, 1969, pp. 163 sq.; C. P. Jones, 1971, p. 99; pace J. M. Bremer, 2005, p. 257 (see following note). Nor is the biographer's assessment consistently more favourable than that advanced by Polybius. Cf. C. B. R. Pelling, 1997, pp. 299-309. Also note H. Trän KLE, 1977, pp. 162-4.

${ }^{10}$ Cf. A. Barzanò, 1994: "agiografia pagana" (p. 406); also idem, 1996, pp. 97-9. However, this view is partly based on a misreading of Aem. 1, which Barzanò takes to indicate a deliberate choice on the part of Plutarch to "eliminare dal suo racconto tutti gli aspetti negativi" (A. Barzanò, 1994, p. 404). For a similar appraisal, cf. W. Reiter, 1988, pp. 97-106. Further note J. M. Bremer, 2005, p. 257, who suggests that both the Flamininus and the Aemilius "come close to hagiography". 
of ancestral customs (Aem. 3.2-7), in political and military affairs (11; $17.4)^{11}$, and as regards the vicissitudes of fortune $(26.8-27.6 ; 36)^{12}$. At Rome, he admirably succeeds in overcoming the common divide between Senate and people, acting as a champion of the aristocracy while at the same time winning the affection of the multitude (38.1sq.; 38.6) ${ }^{13}$. Beyond the capital, too, Aemilius is represented as being held in high esteem even among his enemies (39.7-9), whereas his order to pillage the cities of Epirus is excused as being "contrary to his good and kind nature ( $\pi \alpha \rho \dot{\alpha}$

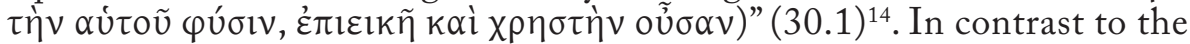
vile and cowardly figure of Perseus ${ }^{15}$, the Roman general thus emerges as a paradigm of wisdom and excellence.

This paper takes a closer look at two spectacular events that epitomise the relationship between Flamininus and Aemilius Paullus on the one hand and the Greek public on the other: the proclamation of liberty at the Isthmian Games in 196 and the victory celebrations at Amphipolis in 167. In both cases, Plutarch not only takes the opportunity to stress the Roman statesmen's 'Hellenic' qualities but also chooses to highlight the concomitant admiration and amazement on the part of the Greeks. Conspicuously, this is expressed in the context of banquets: while Flamininus' policy of liberation is praised by dining Greeks, Aemilius excels as the courteous and attentive host of a Greekstyle feast.

In the Life of Flamininus, the account of the celebrated proclamation of liberty is focused not so much on the protagonist himself as on the historical significance of the declaration and the consequent gratitude of the Greeks. This does not mean that the impact of Flamininus' personality and philhellenic disposition is lost on the reader. For one thing, the episode is preceded by a clear statement to the effect that it was the proconsul himself who insisted on withdrawing the Roman garrisons from the whole of Greece (Flam.10.1-

${ }^{11}$ Also note $31.4-10$ on the education of the people by the consular M. Servilius.

${ }^{12}$ Cf. S. Swain, 1989, pp. 323-7; also M. Pavan, 1961, esp. pp. 602-4 and 609 sq. on Plutarch's elaboration of Aemilius' speeches on $\tau$ x́ $\eta$. In addition, note P. Desideri, 1989, pp. 204-9. More generally, cf. L. L. Holland, 2005 for Plutarch's Aemilius as a philosopher statesman. However, also note V. Pfeifer, 1997, pp. 56-8 on the rejection of passionate impulses as an element of Aemilius' family tradition.

${ }^{13}$ For the antithesis between $\beta$ ou $\lambda \dot{n}$ and $\delta \tilde{\eta} \mu \circ \zeta$ in the Roman Lives cf. esp. C. B. R. Pelling, 1986, pp. 165-87/ 2002, pp. 211-25; also L. DE Blois, 1992 passim; M. MAzza, 1995, esp. pp. 264-8; K. Sion-Jenkis, 2000, pp. 66-9.

${ }_{14}$ On Aemilius' harshness and cruelty towards (some of) the Greeks cf. R. Vianoli, 1972, pp. 87-9; A. BARZANò, 1994, pp. 417-9; IDEM, 1996, pp. 110-2. Also note the emphatic statement in W. REITER, 1988, pp. 141 sq.: "amidst the ruins of seventy cities and one hundred and fifty thousand lives, there is no room for the image of Aemilius as a man of benevolence and humanity". For a balanced assessment, cf. J.-L. Ferrary, 1988, pp. 547-53.

${ }^{15} \mathrm{Cf}$. R. Scuderi, 2004/05 with references. Citing the prominence of the Macedonian king, A. Barzanò, 1994, pp. 405 sq.; IDEM, 1996, pp. 87-90 argues that Aemilius is not even the real protagonist of the Life, but this goes too far. On the elaboration of the theme in the historical tradition beyond Plutarch cf. G. DI LEO, 2003. 
$3)^{16}$. For another, Plutarch subsequently resumes the narrative by praising Flamininus' actions as being consonant with the pledges made at Corinth (Flam. 12.1).

As for the event of the proclamation itself, the protagonist is mainly viewed and characterised through the eyes of the Greek audience ${ }^{17}$. Thus, the assembled multitude is described as watching the athletic contests, as listening to the words of the herald, and as reacting first with tumultuous confusion and then with a vocal outburst of joy, extolling Flamininus

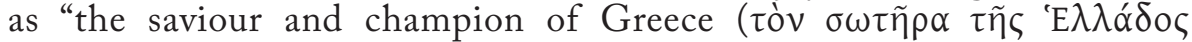

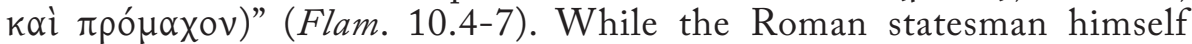
is reported to have retired from the scene, the Greeks are said to have gathered together, shouting about Flamininus' tent until nightfall (Flam. 11.1sq.).

Up to this point, Plutarch's narrative is broadly in agreement with Polybius, who similarly focuses on the expectations and reactions of the crowd before, during, and after the proclamation (Plb. 18 F46.1-12). In his account, which is likely to be Plutarch's main source, this leads on to a number of authorial reflexions on the wider significance of the episode and on the generosity of Flamininus and the Romans (18 F46.13-15). Livy, too, describes the event primarily from the perspective of the Greek audience, though he also makes an observation regarding the joy of the young Flamininus at reaping the concomitant reward of gloria (Liv. 33.32.3-33.3). Moreover, he relates that expressions of gratitude continued for many days, and goes on to depict the Greeks as praising Rome's commitment to the promotion of justice, right, and law (33.33.4-8: ius, fas, lex $)^{18}$.

What follows in Plutarch is something quite different. Having shown enthusiastic appreciation for Flamininus, the multitude continues its celebrations in the Greek fashion: "with greetings and embraces for any friends and fellow citizens whom they saw, they turned around to eat and drink with one another. And here, their pleasure naturally increasing, it occurred to them to reason and discourse ( about Greece" (Flam. 11.2sq.). The event is thus characterised as a spontaneous feast involving an exchange of thoughts and ideas. Significantly, this is an entirely Greek activity, in which the Romans merely figure as objects of reflexion and evaluation. This perspective is further reinforced

${ }^{16}$ Cf. the fuller accounts in Plb. 18 F45.7-12; Liv. 33.31.7-11. In actual fact, this may be quite misleading. Cf. R. Pfeilschifter, 2005, pp. 285-302, who suggests that the discrepancies between the policies favoured by Flamininus and the senatorial commission, respectively, were rather minor. By contrast, the personal factor is stressed by A. M. ECKSTEIN, 1987, pp. 294-302; J. J. WaLsh, 1996, pp. 355-8.

17 On the various functions of public opinion in Plutarch's biographical technique cf. generally F. Frazier, 1996, pp. 110-24.

${ }^{18}$ E. M. Carawan, 1988, pp. 231 suggests that Livy is here "influenced by an annalistic tradition in which the treachery of the allies was given greater emphasis, and Flamininus, for his futile crusade, was held to blame". This may or may not be true. 
at the beginning of the next chapter, which concludes the deliberations of the Greeks while at the same time shifting the narrative focus to the subsequent actions of Flamininus (Flam.12.1).

In the actual debate about the meaning of the proclamation, the name of the proconsul is conspicuous by its absence. In fact, the whole discussion is concerned with the general characteristics of Greece and Rome rather than with the virtues of any individual leader ${ }^{19}$. To be sure, Flamininus is on the reader's mind when Plutarch mentions a number of outstanding generals from

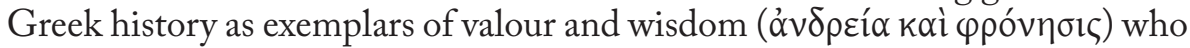
fell short of the ideal of the just man (ó díkolos, Flam. 11.4-6). By implication, the Roman politician is thus judged to be superior to statesmen as eminent as Agesilaus, Lysander, Nicias, and Alcibiades, and his achievements stand comparison with the great victories over the Persians in the first half of the fifth century.

Notwithstanding, the main point of the considerations ascribed to the participants in the banquet is a history lesson about Greece and Rome. Instead of achieving freedom on their own, the Greeks are said to have fought most of their battles to bring servitude (

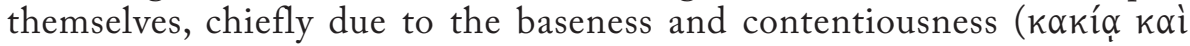

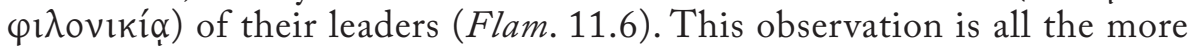
instructive as $\varphi \imath \lambda o v ı k i ́ \alpha$ is the central characteristic of Flamininus' pair Philopoemen, "the last of the Greeks" (Phil. 1.7) ${ }^{20}$. Owing to this lack of common purpose, the liberation of Greece is seen as depending on the intervention of foreigners who would undergo the greatest dangers and hardships in order to set her free from the harshest and most tyrannical despots (Flam. 11.7). Thus, the Greek admirers of Flamininus and the Romans take a remarkably negative view of the whole of Greek history ${ }^{21}$, though Plutarch's readers may well be expected to remember at this point that Rome herself was later to be torn apart by war and civil strife ${ }^{22}$.

Evidently, this is not merely a point about the past. In his political writings, Plutarch insists that bickering, rivalry, and excessive ambition ought to be avoided at a time when concord and consensus appear to serve the interests of the Greek poleis and the local aristocracy under the Roman Empire $^{23}$. As Christopher Pelling has pointed out, he is much more reluctant

${ }^{19}$ This point has also been made regarding the pair as a whole. Cf. C. B. R. Pelling, 1997, pp. 148-53 and 254-258; also J. J. WALsh, 1992, pp. 212-8.

${ }^{20}$ Cf. Phil. 3.1; 17.7; Flam. 22.4; 22.7, with the analysis in C. B. R. Pelling, 1997, pp. 129 35; also J. J. WALSH, 1992, pp. 209-12. Both studies emphasise the relevance of the theme to the pair, on which cf. further C. B. R. Pelling, 1986a, pp. 84-9/ 2002, pp. 350-3. However, also note S. Swain, 1988, pp. 343-5, who stresses the similarity between Philopoemen's pı $\lambda$ ovıkí $\alpha$ and

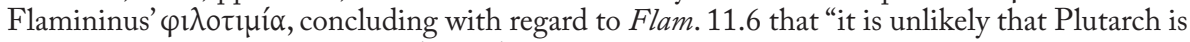
here stigmatizing Philopoemen" (p. 345).

${ }^{21}$ Cf. E. GABBA, 2004, p. 313: "un ragionamento che è di fatto una visione del tutto negativa, o almeno fortemente restrittiva, dell'intiera storia greca classica e dei suoi protagonisti”.

${ }^{22}$ I am grateful to Philip Stadter for suggesting this reading to me.

${ }^{23}$ Cf. esp. Mor. 814e-825f (Praecepta gerendae rei publicae), with the discussions in $\mathrm{P}$. 
in the Lives, most notably in the Pbilopoemen - Flamininus, to spell out moral lessons for his own present ${ }^{24}$. Undoubtedly, the contemporary resonance matters, yet much is left to the reader's interpretation ${ }^{25}$. Interestingly, the following chapter of the Flamininus draws a comparison with Nero's proclamation of liberty in 67 A.D. (Flam. 12.13), which plainly made a strong impression on the Greeks of Plutarch's generation. This reference is preceded by some considerations regarding the appeal of the Romans and the rapid growth of their power, to which everything became subject in the end (Flam. 12.8-10). As for Flamininus himself, however, it is not the subjection but the liberation of Greece which the biographer chooses to underscore, citing the proud inscriptions recording his dedications at Delphi (Flam. 12.11sq.) ${ }^{26}$.

While these final remarks do not alter the fact that Plutarch's treatment of the Isthmian Proclamation is primarily concerned with Greece and with Greek perceptions of Rome, it would obviously be wrong to conclude that the episode is only marginally relevant to the portrait of Flamininus. For one thing, the proconsul is ennobled by the emotional response of the Greek audience and by the favourable comparison with some of the greatest generals of Greek history. For another, the reflexions voiced in the course of the banquet serve to characterise him as a just man and generous benefactor. What is more, his subsequent actions closely match the hopes and expectations of the Greeks as he endeavours to establish among them good order, great justice, concord, and mutual friendliness (Flam. 12.6: عủvouíav

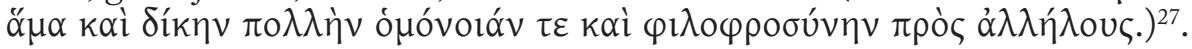
Beyond these political benefactions, Flamininus is also reported to have

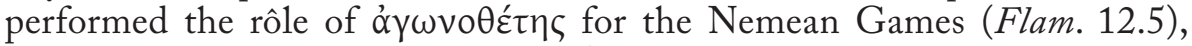
where liberty was proclaimed to the Argives ${ }^{28}$.

This latter aspect of the protagonist's active involvement in the organisation of spectacles emerges much more prominently in the second passage to be discussed in the present paper. In the wake of his victory at Pydna, Aemilius Paullus, too, is described as a benefactor of the Greeks, whose perspective is again highly relevant to the evaluation of a Roman general's actions. Unlike in the account of the Isthmian Proclamation, however, the biographer's focus is mainly on the proconsul himself and on Roman behaviour in front of a Greek audience.

Desideri, 1986; S. Swain, 1996, pp. 161-86.

${ }^{24}$ Cf. C. B. R. Pelling, 1995, esp. pp. 213-7/ 2002, pp. 243-7.

25 Thus, P. Desideri, 1998, pp. 934 sq. suggests that the Flamininus serves to express the idea of a "consortium imperi", in which the Greeks provide "una legittimazione del dominio romano ... in cambio di un privilegio di libertà, anche se non illimitata" (p. 935).

${ }^{26}$ The distinction between Rome and Flamininus is heavily stressed by S. SwaIn, 1988, pp. 342 sq.; idem, 1996, pp. 148 sq.

${ }^{27}$ Cf. also Liv. 34.48.2 and Flamininus' advice to the Greeks at 34.49.9sq.

${ }^{28}$ Cf. Liv. 34.41.1-3. Plutarch decontextualises the event and misleadingly suggests that liberty was once more proclaimed to the whole of Greece. Cf. C. B. R. Pelling, 1997, pp. 384 sq., n. 116. 
Following the surrender of Perseus, Aemilius embarked on an extensive tour of Greece, which Plutarch mainly describes in terms of his hero's philhellenism and benefactions (Aem.28.1-5). Having praised the commander's conduct as

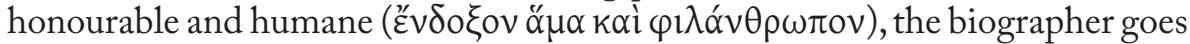
on to record that Aemilius restored political order, offered gifts from the king's stores, and expressed admiration for the Zeus sculpted by Phidias. Apart from this, Plutarch does not fail to mention the general's order to put his own statue on the great monument that was meant to honour Perseus at Delphi (Aem. 28.4 ${ }^{29}$. This demonstration of power as well as Aemilius' interventions in the affairs of the Greek states unmistakably indicate that the trip was not merely a sightseeing tour designed to pay homage to Hellas ${ }^{30}$. As Ulrich Eigler has convincingly argued, Livy actually describes the journey as an act of Roman dominance over Greek culture (Liv. 45.27.5-28.6) ${ }^{31}$. By contrast, the emphasis in Plutarch's narrative is clearly on the protagonist's $\varphi i \lambda \alpha v \theta \rho \omega \pi i$ rather than on the expression of Roman supremacy.

Subsequently, even the harsh conditions imposed on the defeated Macedonians are interpreted as generous benefactions; for the biographer stresses that the former subjects of Perseus received liberty and independence, with their financial burden being less than half the amount due to the Antigonid kings (Aem. 28.6) ${ }^{32}$. Prior to his departure, moreover, Aemilius is depicted as wisely exhorting them to preserve their freedom by good order

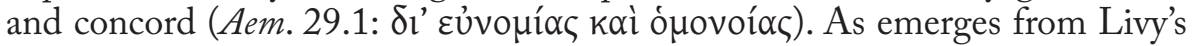
account, the announcement of the terms regarding the future of Macedon formed part of the lavish victory celebrations at Amphipolis (Liv. 45.29-33) ${ }^{33}$, which Plutarch essentially reads as a delightful event organised by the Roman general to please his Greek guests ${ }^{34}$.

Thus, the biographer relates that Aemilius "held spectacles of all sorts of contests and performed sacrifices to the gods, at which he gave feasts and banquets, making use of abundant supplies from the royal stores, while in the arrangement and ordering of them, in seating and greeting his guests, and

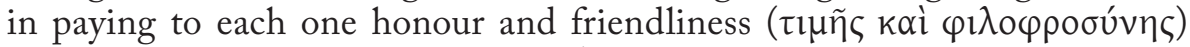
according to their dignity ( $\kappa \alpha \tau^{\prime} \alpha \dot{\alpha}\{\hat{\imath} \alpha v)$, he showed such accurate and

${ }^{29}$ Cf. L.-M. Günther, 1995, who reads this act as a "machtbewußte Siegerpose, keine sympathieheischende Geste philhellener 'paideia"' (p. 84).

${ }^{30}$ This point should not be overstated, however. Cf., e.g., the categorical statement in E. FLAig, 2000, p. 138: "Mit Philhellenismus hatte das nichts zu tun", which may be contrasted with J.-L. FErrary, 1988, pp. 554-60, who speaks of "une véritable offensive de charme" (p. 556), as well as with E. S. Gruen, 1992, p. 246. Further note P. Botteri, 1974/75 (1979), pp. 167 sq., who suggests that Aemilius chiefly sought to acquire foreign clientelae.

31 Cf. U. Eigler, 2003: Livy "inszeniert vielmehr die Tour als einen Akt ideeller Besitzergreifung Griechenlands” (p. 262).

${ }^{32}$ Cf. the more detailed and similarly apologetic treatment in Liv. 45. 29.4-30.8 and 32.1-7, which serves to celebrate the just order established by Rome. Also note D. S. 31 F8.1-9.

${ }^{33}$ On Amphipolis as a place on Livy's 'mental map' of the Roman Empire cf. U. EgelHaAFGaiser, 2006, pp. 49-51.

${ }^{34}$ According to C. Liedmeier, 1935, p. 223, Plutarch's failure to identify the locality indicates that his version is based on the work of a compiler, but this is not cogent. 


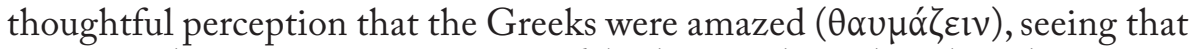
not even their pastimes were treated by him with neglect, but that a man involved in such great affairs gave even to small things their due attention" (Aem. 28.7sq.).

Just as in the case of the Isthmian Proclamation, it is conspicuous that Plutarch views the event through the eyes of the Greeks present on the occasion. Not only are the guests amazed at Aemilius' organisational skills, but their reactions are also thought to show that the Roman general himself provides them with the most pleasant enjoyment and spectacle (Aem. 28.9). While these remarks evidently serve to eulogise the proconsul, it should also be noted that the quality the Greeks admire most of all is his extraordinary attention to detail - a trait that the biographer has earlier associated with his hero's concern for ancestral customs and ceremonies at Rome (Aem. 3.2-7). Accordingly, Aemilius appears successfully to apply skills developed in a Roman context to impress a Greek audience. This point is actually reinforced by his dictum that the same spirit is required to do well both in marshalling a line of battle and in presiding at a symposium (Aem.28.9).

While Plutarch fails to elaborate on this statement, which corresponds to a Polybian fragment (Plb. $30 \mathrm{~F} 14)^{35}$, the laudatory context clearly suggests that it signals the biographer's approval of the carefully arranged order of the banquet $^{36}$. However, it may be more appropriate to read Aemilius' comment not simply as a witty bon mot, let alone as an innocent remark regarding an enjoyable festival, but as a reminder of Roman supremacy in the military sphere and beyond ${ }^{37}$. Significantly, a much less harmonious picture of the victory celebrations emerges from the more comprehensive account given by Livy, who represents the event primarily as a show of Roman maiestas and power ${ }^{38}$. Thus he describes the setting of the ceremony as frightening to the audience (Liv. 45.29.2: novi in<perii> formam terribilem praebuit tribunal), and stresses that Aemilius chose to announce the decisions of the Senate in Latin before having them translated into Greek $(45.29 .3)^{39}$.

${ }^{35}$ Cf. also Liv. 45.32.11; further D. S. 31 F8.13. According to F. W. Walbank, 1979, p. 437, Polybius thus intends "to point the contrast with the victory games given by L. Anicius" at Rome, which are judged by him to have been disorderly and utterly uncivilised (Plb. 30 F22). This may be true but hardly constitutes the sole function of the statement.

${ }^{36}$ Cf. G. Paul, 1991, p. 160. Also note Plu., Mor.198b (Regum et imperatorum apophthegmata); 615e-f (Quaestiones convivales).

${ }^{37}$ Pace R. Flacelière \& E. Chambry, 1966, p. 69, who call it a "boutade". Further note C. Liedmeier, 1935, p. 236: Aemilius "wil als het ware een tweede Achilles zijn, die behalve een verwoed strijder de organisator was van de grootse lijkspelen ter ere van Patroclus".

${ }^{38}$ Cf., e.g., E. S. Gruen, 1992, pp. 245-7. E. Flaig, 2000, pp. 139 sq. puts it more crudely: "Die Feier von Amphipolis war ein römisches Spektakel, eingerahmt von römischer politischer Symbolik, welche die Griechen und ihre Athleten zu Statisten degradierte" (p. 139). A different perspective is provided by J.- L. Ferrary, 1988, pp. 560-5; J. C. Edmondson, 1999, pp. 78-81 and passim, who both stress the importance of Hellenistic precedents and parallels.

${ }_{39}$ Cf. Plu., Cat. Ma. 12.5-7 on Cato's speech to the Athenians in 191. Also note V. Max. 2.2.2. J. Kaimio, 1979 , p. 100 suggests that Aemilius' choice was made with a view to producing a "dramatic effect". 
What is more, Livy highlights Roman interference in the internal affairs of the Greek polities and records the severe punishment of those who had actually or supposedly been aligned with the losing side in the war (45.31). As for the ensuing festival, the admiration of the Greeks is related not so much to Aemilius as to the Romans in general, who were then inexperienced (rudes) in giving spectacles (45.32.10). Consequently, it appears as though a Roman proconsul can outdo the Greeks even in organising Greek-style games and banquets - if he so chooses ${ }^{40}$. While Livy does not fail to mention the gifts handed out to the participants from the royal stores, it is quite revealing that the event is concluded by the dedication of spoils from the enemy and by the display of the booty to be carried off to Rome (45.33.1-7). Thus, the celebrations of Amphipolis are presented to the reader as an eloquent manifestation of the Roman conquest of Greece.

Evidently, this interpretation is rather different from Plutarch's version. Instead of exploring the implications of the event in terms of Roman power, the biographer's narrative goes on to highlight Aemilius' $̇ \lambda \varepsilon \cup \theta \varepsilon p$ เó $\tau \varsigma$ and $\mu \varepsilon \gamma \alpha \lambda \circ \psi v x i \alpha$ as evidenced by his supposed disinterest in the gold and silver of the royal treasuries (Aem. 28.10) ${ }^{41}$. At the same time, Plutarch obviously approves of his hero's decision to appropriate Perseus' library as an invaluable resource of Greek learning for the benefit of his sons (Aem. 28.11) ${ }^{42}$. However, it should not be overlooked that the king's books were undoubtedly of great material and symbolic value as items of booty ${ }^{43}$. What Plutarch reads as enthusiasm for Greek erudition appears simultaneously to reflect a selective and power-conscious approach in claiming and using objects of Hellenic culture $^{44}$. The analysis of the victory celebrations of 167 thus leads back to the issues raised at the beginning of this paper regarding the interrelation between philhellenism and the pursuit of individual and collective interests by the representatives of Rome.

In the Plutarchan accounts of the Isthmian Proclamation and the festival at Amphipolis, there is a deliberate, though hardly surprising, emphasis on 'Hellenic' qualities and benefactions to Greece. In the case of Flamininus and the declaration of 196, it has been seen that the focus is on Greece and Greek history rather than on the protagonist himself, yet Plutarch's narrative also serves to praise the proconsul's justice as being equal or superior to that of

${ }^{40}$ Cf. U. EgelhaAf-Gaiser, 2006, p. 52 with further considerations.

${ }^{41}$ For the theme of Aemilius' poverty and indifference to wealth cf. also Aem. 4.4sq.; 39.10; Tim. 41.8; Mor. 198b-c (Regum et imperatorum apophthegmata) as well as Plb. 18 F35.4-6; 31 F22.1-7; Liv. Per. 46.14; D. S. 31 F26.1 sq.; D. C. 20 F67.1; Zonar. 9.24.4; Cic., Off. 2.76; Orat.232; V. Max. 4.3.8; Vir.ill. 56.6. Cf. I. Shatzman, 1975, pp. 243 sq. for an estimate of his property.

${ }^{42} \mathrm{Cf}$. also Isid., Etym. 6.5.1.

${ }^{43}$ Thus, rightly, A. Barzanò, 1994, p. 413; idem, 1996, pp. 106 and 218, n. 181.

${ }^{44}$ Hence the often stressed difference between Aemilius' outlook and that of Cato (cf., e.g., J.-L. Ferrary, 1988, pp. 535-9) may not be all that great. On the meaning and limitations of Cato's anti-Hellenism cf. D. Kienast, 1954, pp. 101-16; A. E. Astin, 1978, pp. 157-81; E. S. Gruen, 1992, pp. 52-83; H.-J. Gehrke, 1994, pp. 599-607; M. Jehne, 1999. 
the most eminent statesmen of the Greek past. By contrast, the biographer's treatment of the victory celebrations after Pydna is mainly concentrated on Aemilius Paullus' courteous behaviour and outstanding skills in entertaining his guests. What both episodes have in common is not only the context of feasts and spectacles, but also the crucial rôle assigned to the Greek audience and its expressions of admiration and amazement. Consequently, the two Roman statesmen are judged with reference to Greek values, on the basis of their attitude to Greece, and according to their ability to impress the Greek public. Greek-style festivals and the world of the banquet thus provide a most suitable background for presenting the 'liberators' of Greece as exemplars of philhellenism and $\varphi \imath \lambda \alpha v \theta \rho \omega \pi \alpha^{45}$.

\section{Works Cited}

Astin, A. E., Cato the Censor, Oxford, 1978.

Badian, E., Titus Quinctius Flamininus. Philhellenism and Realpolitik, Cincinnati/Ohio, 1970.

BARzAnò, A., "Biografia pagana come agiografia. Il caso della vita plutarchea di Lucio Emilio Paolo", RIL, 128 (1994) 403-24.

"Introduzione" (Emilio Paolo), in IDEM ET AL. (eds.), Plutarco: Vite parallele. Emilio Paolo - Timoleonte, Milano, 1996, pp. 87-116.

Beck, H., Karriere und Hierarchie. Die römische Aristokratie und die Anfänge des cursus honorum in der mittleren Republik, Berlin, 2005.

Botteri, P., "Alcune questioni sulla carriera politica di L. Emilio Paolo", Index, 5 (1974/75 [1979]) 155-78.

Boulogne, J., Plutarque. Un aristocrate grec sous l'occupation romaine, Villeneuve d'Ascq, 1994.

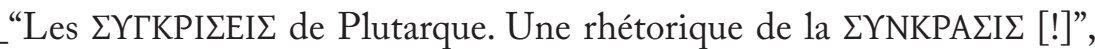
in L. VAn Der Stockt (ed.), Rhetorical Theory and Praxis in Plutarch. Acta of the IVth International Congress of the International Plutarch Society, Leuven, 2000, pp. 33-44.

Bremer, J. M., "Plutarch and the 'Liberation of Greece", in L. De Blois et AL. (eds.), The Statesman in Plutarch's Works. Proceedings of the Sixth International Conference of the International Plutarch Society, vol. 2: The Statesman in Plutarch's Greek and Roman Lives (Nijmegen/ Castle Hernen, May 1-5, 2002), Leiden, 2005, pp. 257-67.

${ }^{45}$ For their paradigmatic function cf., e.g., Plu., Sull.12, where their philhellenic benefactions are favourably contrasted with the cynical policies pursued by Sulla. I am grateful to Lukas de Blois for pointing out to me the significance of this passage. 
Carawan, E. M., "Graecia Liberata and the Role of Flamininus in Livy's Fourth Decade”, TAPhA, 118 (1988) 209-52.

De Blois, L., "The Perception of Politics in Plutarch's Roman 'Lives", $A N R W$, 2.33.6 (1992) 4568-615.

De Romilly, J., La douceur dans la pensée grecque, Paris, 1979.

Desideri, P., "La vita politica cittadina nell'Impero. Lettura dei Praecepta gerendae rei publicae e dell'An seni res publica gerenda sit", Athenaeum, 64 (1986) 371-81.

"Teoria e prassi storiografica di Plutarco. Una proposta di lettura della coppia Emilio Paolo - Timoleonte”, Maia, 41 (1989) 199-215.

"L'Impero bilingue e il parallelismo greci/romani", in S. Setris (ed.), I greci. Storia - cultura - arte - società, vol. 2.3: Una storia greca. Trasformazioni, Torino, 1998, pp. 909-38.

Di Leo, G., “Tra Polibio e Livio. Diodoro e la presunta avarizia di Perseo”, in D. АмваGLIo (ed.), ГУГГРАФН. Materiali e appunti per lo studio della storia e della letteratura antica, vol. 5, Como, 2003, pp. 89-105.

D’Ippolito, G., "Filantropia, ellenocentrismo e polietnismo in Plutarco", in A. Pérez Jiménez \& F. Titchener (eds.), Historical and Biographical Values of Plutarch's Works. Studies Devoted to Professor Philip A. Stadter by the International Plutarch Society, Málaga, 2005, pp. 179-96.

Duff, T. E., Plutarch's Lives. Exploring Virtue and Vice, Oxford, 1999.

Ecrstein, A. M., Senate and General. Individual Decision Making and Roman Foreign Relations, 264-194 B.C., Berkeley/Cal., 1987.

Edmondson, J. C., “The Cultural Politics of Public Spectacle in Rome and the Greek East, 167-166 BCE”, in B. Bergmann \& C. Kondoleon (eds.), The Art of Ancient Spectacle, Washington, D.C., 1999, pp. 77-95.

EgelhaAf-Gaiser, U., "Der triumphierende Leser. Die Siegesfeier von Amphipolis in der Geschichtserzählung des Livius", in D. Elm von Der Osten et Al. (eds.), Texte als Medium und Reflexion von Religion im römischen Reich, Stuttgart, 2006, pp. 41-61.

Eigler, U., "Aemilius Paullus. Ein Feldherr auf Bildungsreise? (Liv. 45, 2728)", in IDEM ET AL. (eds.), Formen römischer Geschichtsschreibung von den Anfängen bis Livius. Gattungen - Autoren - Kontexte, Darmstadt, 2003, pp. 250-67.

Errington, R. M., "Philhellenismus und praktische Politik", in G. VogtSpira \& B. Rommel (eds.), Rezeption und Identität. Die kulturelle Auseinandersetzung Roms mit Griechenland als europäisches Paradigma, Stuttgart, 1999, pp. 149-54. 
Ferrary,J.-L., Philhellénisme et impérialisme. Aspects idéologiques de la conquête romaine du monde hellénistique. De la seconde guerre de Macédoine à la guerre contre Mithridate, Rome, 1988.

Flacelière, R. \& Chambry, E., “Vie de Paul-Emile. Notice”, in indem (eds.), Plutarque: Vies, vol. 4, Paris, 1966, pp. 59-71.

"Vie de Flamininus. Notice", in Indem (eds.), Plutarque: Vies, vol. 5, Paris, 1969, pp. 159-73.

Flaig, E., "Lucius Aemilius Paullus - militärischer Ruhm und familiäre Glücklosigkeit”, in K.-J. Hölkeskamp \& E. Stein-Hölkeskamp (eds.), Von Romulus zu Augustus. Große Gestalten der römischen Republik, München, 2000, pp. 131-46.

Frazier, F., Histoire et morale dans les Vies parallèles de Plutarque, Paris, 1996.

Gabba, E. "Plutarco e Polibio", in I. Gallo (ed.), La biblioteca di Plutarco. Atti del IX Convegno plutarcheo, Napoli, 2004, pp. 311-6.

García Moreno, L. A., "Roma y los protagonistas de la dominación romana en Grecia en las Vidas paralelas de Plutarco", in E. FalQue \& F. Gascó (eds.), Graecia capta. De la conquista de Grecia a la helenización de Roma, Huelva, 1995, pp. 129-47.

"Filohelenismo y moderación. Garantías según Plutarco de una dominación estable del mundo griego por Roma", in J. R. Ferreira (ed.), Actas do Congresso Plutarco Educador da Europa, Porto, 2002, pp. 261-80.

Geнrкe, H.-J., "Römischer mos und griechische Ethik. Überlegungen zum Zusammenhang von Akkulturation und politischer Ordnung im Hellenismus", HZ, 258 (1994) 593-622.

Goldhill, S., Who Needs Greek? Contests in the Cultural History of Hellenism, Cambridge, 2002.

Gruen, E. S., The Hellenistic World and the Coming of Rome, 2 vols., Berkeley/ Cal., 1984.

Culture and National Identity in Republican Rome, Ithaca/N.Y., 1992.

Günther, L.-M., "L. Aemilius Paullus und 'sein' Pfeilerdenkmal in Delphi”, in C. Schubert \& K. Brodersen (eds.), Rom und der griechische Osten. Festschrift für Hatto H. Schmitt zum 65. Geburtstag, Stuttgart, 1995, pp. 81-5.

Holland, L. L., "Plutarch's Aemilius Paullus and the Model of the Philosopher Statesman", in L. De Blois ET AL. (eds.), The Statesman in Plutarch's Works. Proceedings of the Sixth International Conference of the International Plutarch Society, vol. 2: The Statesman in Plutarch's Greek and Roman Lives (Nijmegen/ Castle Hernen, May 1-5, 2002), Leiden, 2005, pp. 269-79. 
Jehne, M., "Cato und die Bewahrung der traditionellen res publica. Zum Spannungsverhältnis zwischen mos maiorum und griechischer Kultur im zweiten Jahrhundert v.Chr.", in G. Vogt-Spira \& B. Rommel (eds.), Rezeption und Identität. Die kulturelle Auseinandersetzung Roms mit Griechenland als europäisches Paradigma, Stuttgart, 1999, pp. 11534.

Jones, C. P., Plutarch and Rome, Oxford, 1971.

Kaimio, J., The Romans and the Greek Language, Helsinki, 1979.

Kienast, D., Cato, der Zensor. Seine Persönlichkeit und seine Zeit, Heidelberg, 1954 (repr. Darmstadt, 1979).

Liedmeier, C., Plutarchus' biographie van Aemilius Paullus. Historische commentaar, Utrecht, 1935.

Martin JR., H. M., “The Concept of Praotes in Plutarch's Lives", GRBS, 3 (1960) 65-73.

"The Concept of Philanthropia in Plutarch's Lives", AJPh, 82 (1961) 164-75.

Mazza, M., "Plutarco e la politica romana. Alcune riconsiderazioni", in I. Gallo \& B. Scardigli (eds.), Teoria e prassi politica nelle opere di Plutarco. Atti del V Convegno plutarcheo, Napoli, 1995, pp. 245-68.

Panagopoulos, C., "Vocabulaire et mentalité dans les Moralia de Plutarque", DHA, 3 (1977) 197-235.

Paul, G., "Symposia and Deipna in Plutarch's Lives and in Other Historical Writings", in W. J. Slater (ed.), Dining in a Classical Context, Ann Arbor/Mich., 1991, pp. 157-69.

Pavan, M., "Due discorsi di Lucio Emilio Paolo", StudRom, 9 (1961) 593613.

Pelling, C. B. R. , "Plutarch and Roman Politics", in I. S. Moxon et Al. (eds.), Past Perspectives. Studies in Greek and Roman Historical Writing, Cambridge, 1986, pp. 159-87 (in C. B. R. Pelling, 2002, pp. 207-36).

"Synkrisis in Plutarch's Lives", in F. E. Brenk \& I. GAllo (eds.), Miscellanea plutarchea. Atti del I Convegno di studi su Plutarco, Ferrara, 1986a, pp. 83-96 (in C. B. R. Pelling, 2002, pp. 349-63).

"Plutarch: Roman Heroes and Greek Culture", in M. Griffin \& J. Barnes (eds.), Philosophia togata. Essays on Philosophy and Roman Society, Oxford, 1989, pp. 199-232.

“The Moralism of Plutarch's Lives", in D. Innes ET AL. (eds.), Ethics and Rhetoric. Classical Essays for Donald Russell on His Seventy-Fifth Birthday, Oxford, 1995, pp. 205-220 (in C. B. R. Pelling, 2002, pp. 237-51). 
"Introduzione" (Filopemene, Tito Flaminino), in IDEm \& E. Melandri (eds.), Plutarco: Vite parallele. Filopemene - Tito Flaminino, Milano, 1997, pp. 87-166, pp. 249-331.

Plutarch and History. Eighteen Studies, London, 2002.

Petrochilos, N., Roman Attitudes to the Greeks, Athens, 1974.

Pfeifer, V., "Deux figures héroïques de l'Histoire romaine de Tite-Live. PaulEmile père et fils", in G. Freyburger \& L. Pernot (eds.), Du héros païen au saint chrétien, Paris, 1997, pp. 53-60.

Pfeilschifter, R., Titus Quinctius Flamininus. Untersuchungen zur römischen Griechenlandpolitik, Göttingen, 2005.

Preston, R., "Roman Questions, Greek Answers. Plutarch and the Construction of Identity", in S. Goldhill (ed.), Being Greek under Rome. Cultural Identity, the Second Sophistic and the Development of Empire, Cambridge, 2001, pp. 86-119.

Reiter, W., Aemilius Paullus. Conqueror of Greece, London, 1988.

Roskam, G., "Plutarch on Self and Others", AncSoc, 34 (2004) 245-73.

Scuderi, R., "Perseo, ultimo sovrano di Macedonia, nella biografia plutarchea di Emilio Paolo", ACD, 40/41 (2004/05) 55-64.

Shatzman, I., Senatorial Wealth and Roman Politics, Bruxelles, 1975.

Silva, M. A. O., "L'identità greca in Plutarco", in J. M. Nieto Ibáñez \& R. López López (eds.), El amor en Plutarco, Actas del IX Simposio español sobre Plutarco (28-30 de septiembre de 2006), León, 2007, pp. 839-46.

Sion-Jenkis, K., Von der Republik zum Prinzipat. Ursachen für den Verfassungswechsel in Rom im historischen Denken der Antike, Stuttgart, 2000.

Swain, S., "Plutarch's Philopoemen and Flamininus", ICS, 13 (1988) 335-47.

"Plutarch's Aemilius and Timoleon", Historia, 38 (1989) 314-34.

"Hellenic Culture and the Roman Heroes of Plutarch",JHS, 110 (1990) 126-45.

Hellenism and Empire. Language, Classicism, and Power in the Greek World, A.D. 50-250, Oxford, 1996.

Tränkle, H., Livius und Polybios, Basel, 1977.

Vianoli, R., "Carattere e tendenza della tradizione su L. Emilio Paolo”, in M. Sordi (ed.), Contributi dell'Istituto di storia antica, vol. 1, Milano, 1972, pp. 78-90. 
Walbank, F. W., A Historical Commentary on Polybius, vol. 3: Commentary on Books XIX-XL, Oxford, 1979.

Walsh, J. J., "Syzygy, Theme and History. A Study in Plutarch's Philopoemen and Flamininus", Philologus, 136 (1992) 208-33.

"Flamininus and the Propaganda of Liberation", Historia, 45 (1996) 344-63. 